\title{
The Dynamic of Inhabitant Identity Card Policy of Indonesia in 2006-2018
}

\author{
Shintya Gugah Asih Theffidy ${ }^{1}$, Muhammad Burhan ${ }^{2}$, and Lusita Anjelina ${ }^{3}$ \\ \{shintyagugah@yahoo.co.id ${ }^{1}$, muhamadburhan92@gmail.com², lusitaanjelina21@gmail.com ${ }^{3}$ \} \\ Student of Master of Government Science Department, Lampung University, Indonesia
}

\begin{abstract}
Public service in the Department of Population Administration and Civil Registration is one of the mandatory functions of the government as regulated in The Law of The Republic of Indonesia Number 23 of 2014 concerning Regional Government. E-KTP is a form of administrative service whereby the state is obliged to provide protection and recognition of the determination of personal status and legal status of any Population and Important experienced by Indonesia Peoples as mandated in The Constitution of Republic of Indonesia in 1945. However, various problems continue to occur, ranging from corruption of e-KTP cases, unrecognized temporary identity certificates and many more. The dynamics of inhabitant Policy is done to overcome the problems related to e-KTP that have existed so far, this is influenced by Four I factors (Ideas, Interests, Institutions, Individuals) and time. Through the inductive approach method through primary and secondary data sources in the form of legal study material and technical analysis of qualitative analysis, this research describes the factors of new ideas, key actors in policy making, the role of institutions, interests and time in the dynamics of the inhabitant policy in Indonesia. Period of 2006-2018. The dynamics of policies related to e-KTP occur as a form of adjustment to create policies that are relevant to the continuity of service in the field of the occupation administration, therefore strengthening supervision is not only the responsibility of law enforcement institutions or authorized institutions but all of the Indonesian Peoples.
\end{abstract}

Keywords: Administrative Services; e-KTP; Dynamic of Policy; Regulation; Four I

\section{Introduction}

Organizing public services is the government's responsibility to Indonesia Peoples The purpose of providing public services is to fulfill the needs of the rights of every citizen and resident of an item and administrative service provided by the government related to the public interest. One type of public service which is the obligation of the government and has a strategic role because it is one of the obligatory functions of the government is public service in the department of population and civil registration. The State is obliged to provide protection and recognition of the determination of personal status and legal status of any Population and Important Events experienced by the Population and/or Indonesian Peoples as mandated in The 1945 Constitution of the Republic of Indonesia.

Referring to The Law of Republic of Indonesia Number 24 of 2013 concerning Amendments to The Law of Republic of Indonesia Number 23 of 2006 concerning Inhabitant Administration, regulating that Inhabitant Administration is a series of structuring and 
controlling activities in the issuance of documents and Inhabitant Data through Population Registration, Civil Registration, Inhabitant Administration information management and the utilization of the results for public services and the development of other sectors. Previously, non-electronic Identity Cards were valid in Indonesia until December 31, 2004, which were eventually replaced by Electronic Identity Cards. In the Law, it is also explained that Electronic Identity Cards (hereinafter referred to as e-KTP) is Identity Cards equipped with chips which constitute the official identity of the inhabitant as self-proof issued by the Implementing Agency.

E-KTP is an integral part of inhabitant administration and its implementation must be orderly. Orderly population administration is intended as protection and recognition of the certainty of personal status and legal status of the inhabitant in the life of the community, nation and state, therefore the focus of this policy study focuses on the dynamics of the e-KTP policy, as diagram follows:

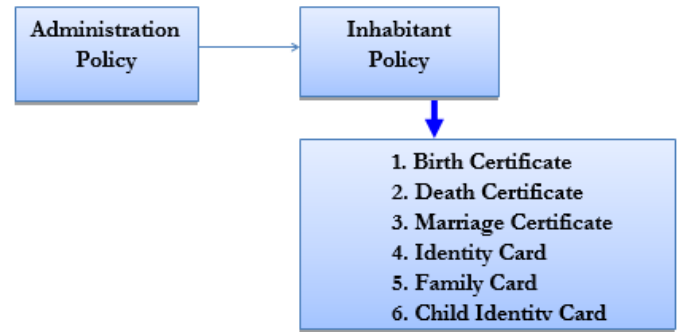

Fig 1. The Map of Administrative Policy with the focus of the e-KTP study

Prior to the issuance of Law Number 23 of 2006 concerning Inhabitant Administration, arrangements regarding Inhabitant Administration, including arrangements for Inhabitant Identity Cards (KTP) were regulated by the regulations of the Dutch East Indies Colonial Government (Staatsblad) and the Ministerial regulation Then The Law of Republic of Indonesia Number 23 of 2006 concerning Population Administration was only issued after 61 years of independent Indonesia. In its development, The Law of Republic of Indonesia Number 24 of 2013 was published amendments to the Law of Republic of Indonesia Number 23 of 2006 concerning Population Administration.

In its journey, the implementation of the e-KTP program was inseparable from various obstacles, namely the corruption case of the e-KTP congregation which until now is still in the handling of the Corruption Eradication Commission (KPK), rejection of e-KTP Substitute Certificate in various banks. Issuance of Circular Letter (SE) from Minister of Home Affairs of the Republic of Indonesia Number: 471.13 / 10231 / Dukcapil, Subject: Format of Certificate of Substitution as e-KTP as a result of scarcity of e-KTP, network problems, and much more. Therefore, referring to the complexity of the e-KTP problem in Indonesia, there needs to be a study that shows the dynamics of policies related to Inhabitant Identity Cards (eKTP) as the basic needs of Indonesian people for their personal status and legal status for each incident and important events.

\subsection{Literature Review \\ Policy Dynamics}

Dynamics always occur over time, in any aspect. Dynamics means that one person's behavior directly influences the other citizens reciprocally, therefore dynamics means that there are interaction and interdependence between members of one group with the other group 
members reciprocally and between members and the group as a whole. Dynamics occur over time because of various factors. There are 4 (four) factors that influence the context of policy change. These 4 factors are 4I: ideas, interests, institutions, and individuals as policymakers. In addition, as research that spans a period spanning more than half a century, the effect of time becomes very important. Further explained as follows:

1. Ideas and Individuals:

There is a main factor, namely the presence of new ideas that enter and are absorbed into the interests and institutions that bring about a paradigm shift in policy. In the process of new ideas, there are key individuals/actors who will carry out various roles, especially their role as responsible actors. These new ideas can emerge from the political elite (Stakeholders, Leaders, Leaders) and from the community itself.

2. Ideas and interests:

New ideas that arise are also influenced by various interests in order to push the issue of a paradigm shift in policy. In the political sphere, this is done by people who have influence. Usually, it can also be influenced by cultural changes or new adaptations, which then arise from the interest groups who fight for it.

3. Institutions:

Institutions are a forum for delivering new ideas related to policy changes. In terms of institutions, the policy will be influenced by an idea that is indeed considered to be time to apply. Then the institution encourages the idea to be legitimate by submitting it to the authorities (government). Changes in policy from an institutional perspective are caused by conflicts between current regulations and conditions, therefore, they are deemed necessary to adapt with more relevant policies applied.

4. Individual Roles:

Individuals are the main actors as the key to policy change. Individuals have a role in incorporating new ideas in policy either as a giver of ideas, forming ideas or as recipients of new ideas that are proposals from other actors. Individuals who act as key actors have the authority to determine policy changes while being responsible for changing those policies.

5. Time as an important element in policy dynamics:

Policies are also influenced by time, both regarding policies that are deemed necessary to change because they have been long enough or at times that cannot be predicted because they need to be applied at that time. This proves that the time factor is one of the important elements of policy dynamics.

From the explanation above, it can be seen that policy dynamics can occur due to various factors. First, new ideas (policies can be influenced by new ideas that are considered more strategic). Second, Individuals / Actors (have an important role in setting and taking a policy), Third Institutions (Policies are influenced by laws, norms, rules, by institutions that authority to do so), Fourth Interest (political lobbying occurs, certain interests arise from certain groups). Last is time, policies also follow developments from time by time so that they remain relevant.

\section{e-KTP Public Services}

Public policy must be developed by prioritizing change in the public sector so that the reform movement in the public sector can move faster than previously attempted by public policy. Public policy must thus avoid the orthodox mindset to solve public problems that are increasingly complex and complicated. Therefore public policy requires adjustment and experiencing dynamics. Policy as a behavior that is permanent and repetitive in relation to the 
business that is inside and through the government in order to solve common problems that occur. It can be concluded that the policy is an action taken to achieve the goal.

Service basically be defined as the activity of a person, group and/or organization both directly and indirectly to meet needs . E-KTP service is part of Administrative Services as referred to in Article 5 paragraph (7) letter a of The Law Number 25 of 2009 concerning Public Services, namely government administrative actions that are required by the state and regulated in legislation in order to realize personal protection, family, honor, dignity and property of citizens.

\section{Methods}

The research writing method is normative jurisdiction, which is supported by the inductive approach method. This research was carried out with the new regulations specifically to more general rules of character. By using data sources, primary data and secondary data, namely in the form of primary, secondary legal materials. The analysis used is a technique of qualitative normative analysis.

\section{Results and Discussion}

Since 2006 until 2018, the dynamics of the Inhabitant Identity Card (KTP) policy has occurred in Indonesia, from the change of KTP to e-KTP, changes in the validity period of the KTP which was previously only 5 years and must be displayed, afterward, it changes to be valid for lifetime. The dynamics of the policy regarding the Inhabitant Identity Card (KTP) does not only stop when the change to become e-KTP, but there are also various other factors that cause adjustments to other related regulations. Therefore, over time the population administration policy, especially e-KTP, continued to be adjusted. In addition to experiencing changes from time by time, in policy dynamics, it is possible for a policy to also change. This can be seen through the description of the changes in the setting substance and the change of setting substance as shown in the following table:

Table 1. Changes in the Substance of e-KTP Arrangement

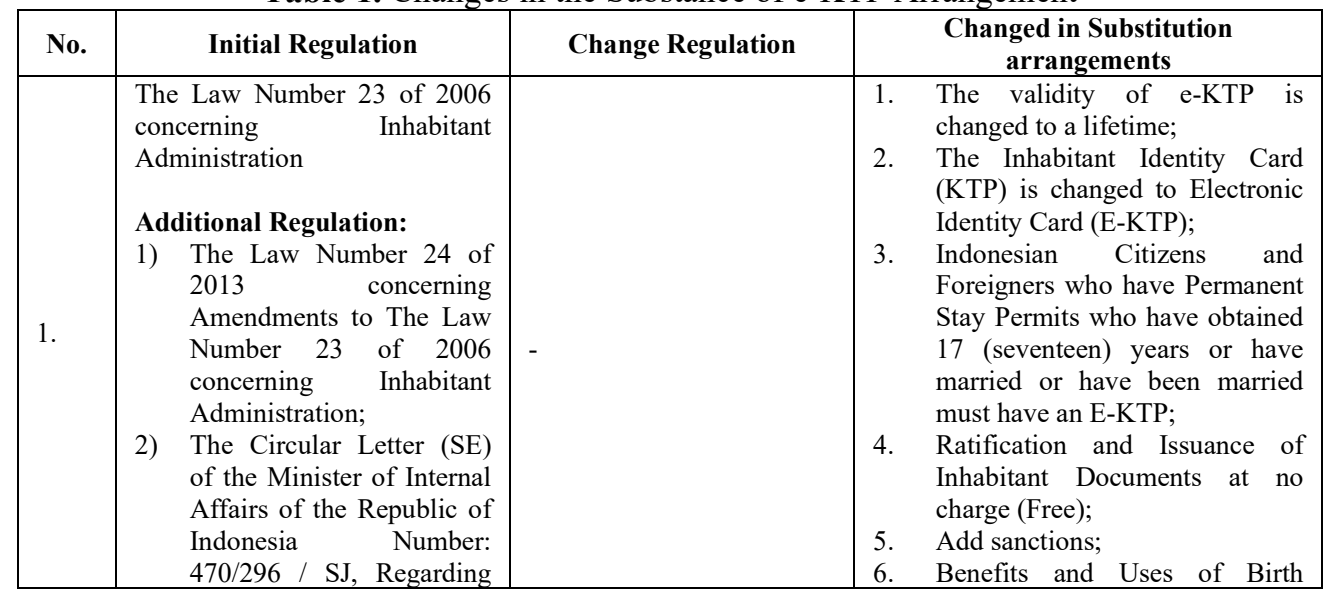




\begin{tabular}{|c|c|c|c|c|}
\hline & $\begin{array}{l}\text { Electronic KTP }(\mathrm{e}-\mathrm{KTP}) \\
\text { Valid for Lifetime }\end{array}$ & & & Certificates. \\
\hline 2. & $\begin{array}{l}\text { The Government Regulation } \\
\text { Number } 37 \text { of } 2007 \text { concerning } \\
\text { Implementation of The Law } \\
\text { Number } 23 \text { of } 2006 \\
\text { Additional Regulation: } \\
\text { The Government Regulation } \\
\text { Number } 102 \text { of } 2012 \\
\text { Amendment to The } \\
\text { Government Regulation } \\
\text { Number } 37 \text { of } 2007 \text { concerning } \\
\text { Implementation of Law } \\
\text { Number } 23 \text { of } 2006 \text {. }\end{array}$ & - & & $\begin{array}{l}\text { Additions to SIAK (Inhabitants } \\
\text { Administration Information } \\
\text { System); } \\
\text { Maintenance, security, and } \\
\text { supervision, including data in } \\
\text { the database, hardware, } \\
\text { software, data communication } \\
\text { networks, data centers, data } \\
\text { backup, and backup data } \\
\text { centers; } \\
\text { Distribution of authority for } \\
\text { funding allocation by the } \\
\text { Government, provincial } \\
\text { government and regional / city } \\
\text { government, as well as financing } \\
\text { data communication networks. }\end{array}$ \\
\hline 3. & $\begin{array}{l}\text { The Presidential Regulation of } \\
\text { the Republic of Indonesia } \\
\text { Number } 25 \text { of } 2008 \text { concerning } \\
\text { Requirements and Procedures } \\
\text { for Registration of Population } \\
\text { and Civil Registration }\end{array}$ & $\begin{array}{l}\text { The Presidential } \\
\text { Regulation of the Republic } \\
\text { of Indonesia Number 96 of } \\
2018 \text { concerning } \\
\text { Requirements and } \\
\text { Procedures for Registration } \\
\text { of Population and Civil } \\
\text { Registration }\end{array}$ & 3) & $\begin{array}{l}\text { The Presidential Regulation } \\
\text { Number } 25 \text { of } 2008 \text { concerning } \\
\text { Requirements and Procedures } \\
\text { for Inhabitant Registration and } \\
\text { Civil Registration is revoked and } \\
\text { declared invalid; } \\
\text { Adjustment to The Law Number } \\
24 \text { of } 2013 \text { concerning } \\
\text { Amendments to The Law } \\
\text { Number 23 Year } 2006 \\
\text { concerning Population } \\
\text { Administration; ration consists } \\
\text { Inhabitant registration } \\
\text { of recording population data, } \\
\text { issuance of family cards, } \\
\text { issuance of E-KTP (Electronic } \\
\text { Identity Card), Child Identity } \\
\text { Card, issuance certificate of } \\
\text { residence and inhabitant } \\
\text { registration of vulnerable } \\
\text { inhabitant Administration; } \\
\text { The Electronic Inhabitant } \\
\text { Identity Card (e-KTP) does not } \\
\text { require an RT / RW and Village } \\
\text { Head certificate anymore. }\end{array}$ \\
\hline 4. & $\begin{array}{l}\text { Presidential } \\
\text { Number } 26 \text { of } 2009 \text { concerning } \\
\text { Application of Inhabitant } \\
\text { Identity Cards Based on } \\
\text { National Population Number } \\
\text { Additional Regulation: } \\
\text { 1) The Presidential } \\
\text { Regulation of the } \\
\text { Republic of Indonesia } \\
\text { Number 35 of 2010 } \\
\text { concerning Amendment } \\
\text { to Presidential Regulation } \\
\text { Number 26 of 2009 } \\
\text { concerning Application of }\end{array}$ & - & 2) & $\begin{array}{l}\text { The description of the E-KTP } \\
\text { and the validity period of the } \\
\text { Non-electronic KTP only until } \\
\text { December } 31,2004 \text {; } \\
\text { Government agencies, local } \\
\text { governments, banking } \\
\text { institutions, and the private } \\
\text { sector must provide services to } \\
\text { the public based on the E-KTP } \\
\text { by not considering the E-KTP } \\
\text { publishing place; } \\
\text { Government Agencies, Regional } \\
\text { Governments, and Banking } \\
\text { Institutions must report on the } \\
\text { implementation of services to } \\
\text { the President through the }\end{array}$ \\
\hline
\end{tabular}




\begin{tabular}{|c|c|c|c|c|c|}
\hline & 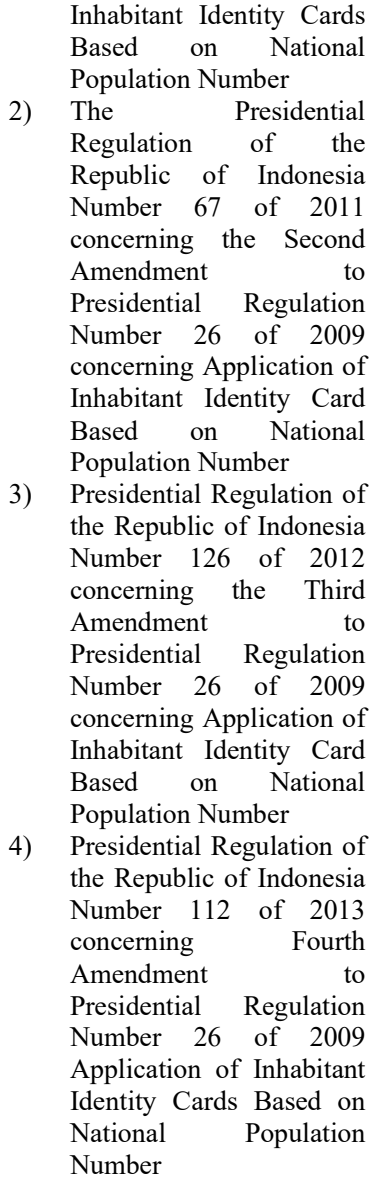 & & & & $\begin{array}{l}\text { Minister every } 6 \text { (six) months up } \\
\text { to December } 31,2014 \text {. }\end{array}$ \\
\hline 5. & $\begin{array}{l}\text { The Minister of Home Affairs } \\
\text { Regulation Number } 9 \text { of } 2011 \\
\text { concerning Guidelines for } \\
\text { Issuance of Inhabitant Identity } \\
\text { Cards Based on National } \\
\text { Population Number }\end{array}$ & & 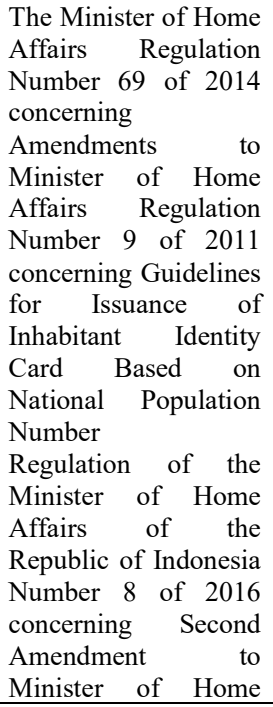 & 2) & $\begin{array}{l}\text { Minister of Home Affairs } \\
\text { Regulation Number } 69 \text { of } 2014 \\
\text { concerning Amendment to } \\
\text { Minister of Home Affairs } \\
\text { Regulation Number } 9 \text { of } 2011 \\
\text { concerning Guidelines for } \\
\text { Issuance of Inhabitant Identity } \\
\text { Card Based on National } \\
\text { Population Registration } \\
\text { Numbers revoked and declared } \\
\text { invalid; } \\
\text { Inhabitant Identity Card (KTP) } \\
\text { changed to Electronic Inhabitant } \\
\text { Identity Card (E-KTP); } \\
\text { Central Server Integrated } \\
\text { Database Management System, } \\
\text { hereinafter referred to as the } \\
\text { Central IDMS server; } \\
\text { Requirements and procedures } \\
\text { for issuing E-KTP for } \\
\text { Indonesian citizens do not have } \\
\text { an E-KTP; }\end{array}$ \\
\hline
\end{tabular}




\begin{tabular}{|c|c|c|c|c|}
\hline & & $\begin{array}{l}\text { Affairs Regulation } \\
\text { Number } 9 \text { of } 2011 \\
\text { concerning Guidelines } \\
\text { for Issuance of } \\
\text { Inhabitant Identity } \\
\text { Card Based on } \\
\text { National Population } \\
\text { Number. }\end{array}$ & 5) & $\begin{array}{l}\text { Recording and Issuance of E- } \\
\text { KTP. }\end{array}$ \\
\hline 6. & $\begin{array}{l}\text { The Law Number } 23 \text { of } 2006 \\
\text { concerning citizens } \\
\text { Administration } \\
\text { Additional Regulation: } \\
\text { The Minister of Home Affairs } \\
\text { Regulation Number } 19 \text { of } 2018 \\
\text { concerning Quality } \\
\text { Improvement of Population } \\
\text { Services }\end{array}$ & 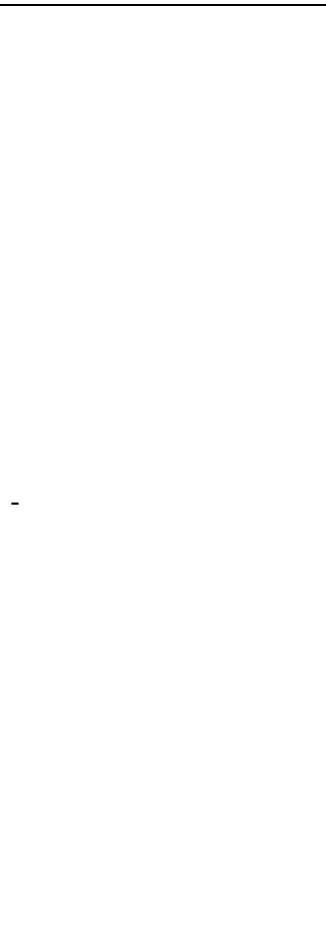 & 2) & $\begin{array}{l}\text { Increasing the quality of } \\
\text { population administration } \\
\text { services is carried out at the } \\
\text { Regency / City Population and } \\
\text { Civil Registration Service; } \\
\text { Can do integrated services } \\
\text { and/or come immediately; } \\
\text { The following documents: } \\
\text { Family Card, E-KTP, Birth } \\
\text { Certificate, Marriage Certificate, } \\
\text { Death Certificate, and Moving } \\
\text { Certificate are completed within } \\
1 \text { (one) hour and no later than } 24 \\
\text { (twenty four) hours from the } \\
\text { time the requirement is declared } \\
\text { complete, except when it occurs } \\
\text { disruption of } \\
\text { communication networks and/or } \\
\text { facilities related to settlement of } \\
\text { population documents; } \\
\text { Regents / Mayors must facilitate } \\
\text { the improvement of the quality } \\
\text { of services for population } \\
\text { administration; } \\
\text { Providing complaint services, } \\
\text { announcing the names of } \\
\text { documents published every day } \\
\text { and the number of blank E-KTP } \\
\text { every day. }\end{array}$ \\
\hline 7. & $\begin{array}{l}\text { Article } 65 \text { of Law Number } 23 \\
\text { of } 2006 \text { concerning Population } \\
\text { Administration, regulates the } \\
\text { Population Certificate, as well } \\
\text { as the availability factor of E- } \\
\text { KTP blanks that have been } \\
\text { exhausted. } \\
\text { Additional Regulation: } \\
\text { Circular Letter (SE) of the } \\
\text { Minister of Home Affairs of the } \\
\text { Republic of Indonesia Number: } \\
471.13 \text { / 10231 / Dukcapil, } \\
\text { Subject: Format of Certificate } \\
\text { of Substitution for E-KTP }\end{array}$ & - & 2) & $\begin{array}{l}\text { Citizens who have recorded } \\
\text { PRR (Print Ready Record) can } \\
\text { use a Substitute Certificate of E- } \\
\text { KTP; } \\
\text { Substitute Certificate of E-KTP } \\
\text { is used for the benefit of } \\
\text { Elections, Banking, } \\
\text { Immigration, Police, Insurance, } \\
\text { BPJS, Marriage, and other needs } \\
\text { according to regional needs. }\end{array}$ \\
\hline
\end{tabular}

\section{Idea and Individual}

Previously, arrangements regarding Population Administration, including arrangements for the Inhabitant Identity Card (KTP), were governed by the regulations of the Dutch East Indies Colonial Government (Staatsblad) and at the level of Ministerial Regulations. Until new idea emerged to provide protection and recognition of the determination of personal status and 
legal status of anyone and Significant Events experienced by Indonesian Citizens as mandated in the 1945 Constitution of Republic of Indonesia with the issuance of The Law Number 23 of 2006 concerning Population Administration.

Nowadays, The Law Number 23 of 2006 concerning Population Administration has been amended by The law Number 24 of 2013 concerning Amendment to The Law Number 23 of 2006 concerning Population Administration which changes the policy on non-electronic KTP to Electronic KTP that are valid for a period of life, the role of the actor responsible in this case is the Minister of Home Affairs. Including the issuance of Circular Letter (SE) of the Minister of Home Affairs of the Republic of Indonesia Number: 470/296 / SJ, Regarding Electronic KTP (e-KTP) Valid for Life.

\section{Idea and Interests}

Policy changed related to The Law Number 24 of 2013 concerning Amendments to The Law Number 23 of 2006 concerning Population Administration which emphasize the existence of sanctions for the administration of population administration services, in order to encourage interests built by the Government to administer population administration as applicable regulations. Another thing is that the application of E-KTP is acknowledged to be corrupted in congregation, as if this policy was made for malicious purposes, the impact when the scarcity of blank is issued Circular (SE) Minister of Home Affairs of the Republic of Indonesia Number: 471.13 / 10231 / Dukcapil, Regarding: Format of Certificate as Substitute for E-KTP, when the situation requires that the E-KTP form be empty (2016) even though many citizens have obtained PRR status (Print Ready Record).

\section{Institutions and Ideas}

Amendment Policy Number 102 of 2012 Amendments to Government Regulation Number 37 of 2007 concerning Implementation of The Law Number 23 of 2006 which shows policy changes that are encouraged by institutions. Distribution of the authority of the financing budget by the Government, the provincial government and the regional / city government, as well as financing the data communication network. Furthermore, the Presidential Regulation of the Republic of Indonesia Number 96 Year 2018 concerning Requirements and Procedures for Registration of Population and Civil Registration which eliminates policies related to cover letters from RT / RW, so that the public can immediately record the nearest residence. There is an institutional push on top of it (executive) related to the elimination/cutting of complicated bureaucracy in the administrators of population administration services.

Furthermore, related to the Republic of Indonesia Number 112 of 2013 concerning the Fourth Amendment to Presidential Regulation Number 26 of 2009 Application of Inhabitants Identity card Based National Number Identity, that mandating Government Agencies, Regional Governments, Banking Institutions, and Private Services must provide services to residents with the basis of E-KTP by not considering the place of issue of E-KTP, therefore that regulation is binding on concerned institutions.

\section{Role of Individuals}

Substitute Certificate of E-KTP used for the purposes of Elections, Banking, Immigration, Police, Insurance, BPJS, Marriage and other needs according to regional needs, based on Circular (SE) Minister of Home Affairs of the Republic of Indonesia Number: 471.13 / 10231 / Dukcapil, Regarding: Format of Certificate of Substitution for E-KTP which shows the existence of individuals (in this case the Minister of Home Affairs) as policymakers for relevant institutions. Furthermore, in the Minister of Home Affairs Regulation No. 19 of 2018 
concerning Improving the Quality of Inhabitant Services, it requires the Regent / Mayor to provide a means of improving service quality. Regents / Mayors as individuals who play a role (key actors) in accelerating the improvement of the quality of population services.

\section{Time as Important Element of Policy Dynamics}

Time also has a strong factor in policy dynamics. For example, Regulation of the Minister of Home Affairs of the Republic of Indonesia Number 8 of 2016 concerning Second Amendment to Minister of Home Affairs Regulation Number 9 of 2011 concerning Guidelines for Issuance of inhabitant Identity Cards Based on National Population Identification Numbers which regulates further National-Based Registration by utilizing the EKTP chip, as well as the Central Server Integrated Database Management System, hereinafter referred to as the IDMS Central server as a population data center that adapts to the development of the digitalization world. Furthermore, the issuance of the Presidential Regulation of the Republic of Indonesia Number 96 of 2018 concerning Requirements and Procedures for Registration of Inhabitant and Civil Registration, as an adjustment to the issuance of The Law 24 of 2013 concerning Population Administration also Minister of Home Affairs Regulation Number 19 of 2018 concerning Quality Improvement of Population Services which requires to issue E-KTP within 1 (one) hour and no later than 24 (twenty four) hours since the requirements are declared complete, including announcing the names printed and the number of blanks every day. This policy is relevant to the current situation, considering the many demands of the community for quality services, as well as the certainty of public information.

\section{Conclusion and Recommendation}

The dynamics of the policy on population administration in Indonesia. occur in several ways, both related to the Population Administration Law, Government Regulations, Presidential Regulations, and the Minister of Home Affairs Regulation. Policy dynamics arise as a result of various factors, namely $4 \mathrm{I}$ (Ideas, Individuals, Institutions, Interest). First, new ideas (policies can be influenced by new ideas that are considered more strategic), Second, individuals/actors (have an important role in setting and taking a policy). Third, Institution (policy rules by law, norms, rules, and related institutions without commitment). Fourth Interest (political lobbying occurs, certain interests emerge from certain groups), The last is time. The policy also follows developments from time by time to keep them relevant.

The dynamics of the E-KTP policy need to be understood that the emergence of new ideas should be purely a public need so that it is not a product of the interests of certain groups. For this reason. First, public awareness must be built to safeguard this problem. The second is related to the role of the individual as a key factor in taking policy must be seen from the beginning, so that the motive for making clear decisions is in the interests of citizens. In addition, the background and competencies of these key actors must be experts both scientifically and in the field so that there is no longer a dynamic term of "trial and error" policy. The third is related to institutions. It is necessary to conduct joint escort and improve coordination relations between institutions so that each policy product does not overlap with each other, on the contrary, it reinforces each other. Fourth, regarding the importance of the need for strengthening supervision, especially for individual law enforcers who are also supported by the community. How can a policy be full of lobbying and certain interests, therefore the institutional strengthening of supervision and strict sanctions is highly recommended. 
Last time as a supporting element, certain adjustments need to be made as soon as possible considering that currently entering the industrial 4.0 error example, E-KTP services via digital, mobile recording E-KTP, and transparency of people who have obtained status (PRR) so that there is legal certainty regarding administrative services. The dynamics of policies related to E-KTP occur as a form of adjustment for the creation of policies that are relevant to the continuity of services in the field of the occupation administration, therefore supervision is not only the responsibility of authorized institutions but all Indonesian peoples. It can support the creation of legal certainty and recognition of the personal status of each resident in the territory of the Unitary Republic of Indonesia.

\section{References}

[1] Abidin, Said Z. 2004. Kebijakan Publik. Jakarta: Yayasan Pancur Siwah.

[2] Dwiyanto, Indiahono. 2009. Kebijakan Publik Berbasis Dynamic Policy Analisys. Yogyakarta: Gava Media.

[3] Dudley Geoffrey and Richardson Jeremy, 2005. Why Does Policy Change? Lessons from British Transport Policy 1945-99. Routledge; New York.

[4] Amalia, Diah Ayu. (2017). Dinamika Kelompok Dalam Kelompok Usaha Bersama: Kasus Kube Cempaka dan Kube Tulip di Kota Bogor. Jakarta: Jurnal Ilmiah Pusat Penelitian dan Pengembangan Kesejahteraan Sosial, Kementerian Sosial Republik Indonesia.

[5] Siregar, Parmahonan. (2014). Pengaruh Implementasi Kebijakan Kependudukan dan Kualitas Pelayanan Masyasrakat Terhadap Kepuasan Masyarakat dalam Pembuatan KTP Elektronik pada Kantor Catatan Sipil Bekasi Selatan. Program Studi Magister Ilmu Administrasi, Universitas Prof. DR. Moestopo (Beragama).

[6] The Law of Republic of Indonesia Number 25 of 2009 concerning Public Services. 2009. Jakarta.

[7] The Law of Republic of Indonesia Number 23 of 2006 concerning Inhabitant Administration. 2006. Jakarta.

[8] The Law of Republic of Indonesia Number 24 of 2013 concerning Amendments to The Law of Republic of Indonesia Number 23 of 2006 concerning Inhabitant Administration. 2013. Jakarta.

[9] The Government Regulation Number 37 of 2007 concerning Implementation of The Law Number 23 of 2006. 2007. Jakarta.

[10] The Government Regulation Number 102 of 2012 Amendment to The Government Regulation Number 37 of 2007 concerning Implementation of The Law Number 23 of 2006 concerning Population Administration. 2012. Jakarta.

[11] The Presidential Regulation of the Republic of Indonesia Number 25 of 2008 concerning Requirements and Procedures for Registration of Population and Civil Registration. 2008. Jakarta.

[12] The Presidential Regulation of the Republic of Indonesia Number 96 of 2018 concerning Requirements and Procedures for Registration of Population and Civil Registration. 2018. Jakarta.

[13] The Presidential Regulation Number 26 of 2009 Application of Inhabitant Identity Card Based on National Inhabitant Numbers. 2009. Jakarta.

[14] The Republic of Indonesia Presidential Regulation Number 112 of 2013 concerning Fourth Amendment to Presidential Regulation Number 26 of 2009 Application of Inhabitant Identity Cards Based on National Inhabitant Number. 2013. Jakarta.

[15] The Minister of Home Affairs Regulation Number 9 of 2011 concerning Guidelines for Issuance of Inhabitant Identity Cards Based on National Population Number. 2011. Jakarta.

[16] The Regulation of the Minister of Home Affairs of the Republic of Indonesia Number 8 of 2016 concerning Second Amendment to Minister of Home Affairs Regulation Number 9 of 
2011 concerning Guidelines for Issuance of Inhabitant Identity Cards Based on National Inhabitant Number. 2016. Jakarta.

[17] The Minister of Home Affairs Regulation Number 19 of 2018 concerning Quality Improvement of Inhabitant Services. 2018. Jakarta.

[18] The Circular Letter (SE) of the Minister of Home Affairs of the Republic of Indonesia Number: 470/296 / SJ, Regarding Electronic KTP (E-KTP) Valid for a Lifetime. 2016. Jakarta.

[19] The Circular Letter (SE) of the Minister of Home Affairs of the Republic of Indonesia Number: 471.13/10231/Dukcapil, Regarding Format of Certificate as a Substitute for E-KTP. 2016. Jakarta.

[20] The Department of Home Affairs of the Republic of Indonesia. (2018, 20 November). Sejarah KTP di Indonesia.

[21] Republika. (2018, 5 Desember). KPK: Penanganan Korupsi E-KTP Belum Selesai.

[22] Tribun News Batam. (2017, 7 Maret). Surat Keterangan Pengganti E-KTP Ditolak Bank, Ini Kata OJK. 